\title{
Three-dimensional modeling of DCIR and identification of new drugs blocking HIV-1 attachment and propagation
}

\author{
Caroline Gilbert*, Arezki Azzi, Alexandra A Lambert, Sheng-Xiang Lin, Geneviève Allaire, Karianne P St-Gelais, \\ Michel J Tremblay
}

From 17th International Symposium on HIV and Emerging Infectious Diseases (ISHEID) Marseille, France. 23-25 May 2012

\section{Introduction}

The HIV-1 pandemic continues to expand while no effective vaccine is yet available. Finding new therapeutic targets and drugs is therefore crucial. We have previously shown that the dendritic cell immunoreceptor (DCIR), a C-type lectin receptor expressed in dendritic cells (DCs), acts as an attachment factor for HIV-1 to DCs and contributes to HIV-1 transmission to CD4+ T lymphocytes (CD4TL). Directly involved in HIV-1 infection, DCIR is expressed in apoptotic or infected CD4TL and promotes trans-infection to bystander cells. The aim of the present study is to characterize the extracellular domain of DCIR and to test chemical inhibitors of HIV-1 attachment thereto.

\section{Results}

We present the first three-dimensional model of DCIR structure. Based on this structure, several inhibitors were selected to target viral interaction with the carbohydrate recognition domain and the EPS motif. Preliminary screening using Raji-CD4-DCIR cells identified two inhibitors that decreased HIV-1 attachment and propagation. These inhibitors did not affect the proliferation of peripheral blood mononuclear cells.

\section{Conclusions}

The results of this study thus suggest structures for novel molecules capable of blocking HIV-1 transmission by DCs and CD4TL.

\footnotetext{
* Correspondence: caroline.gilbert@crchul.ulaval.ca Laval University, Québec, Canada
} and take full advantage of:

- Convenient online submission

- Thorough peer review

- No space constraints or color figure charges

- Immediate publication on acceptance

- Inclusion in PubMed, CAS, Scopus and Google Scholar

- Research which is freely available for redistribution

Submit your manuscript at www.biomedcentral.com/submit
() Biomed Central

\footnotetext{
(c) 2012 Gilbert et al; licensee BioMed Central Ltd. This is an Open Access article distributed under the terms of the Creative Commons BioMed Central any medium, provided the original work is properly cited.

\author{
Cite this article as: Gilbert et al:: Three-dimensional modeling of DCIR \\ and identification of new drugs blocking HIV-1 attachment and \\ propagation. Retrovirology 2012 9(Suppl 1):P9.
}

